\title{
Genetic Relationships of Body Measurements at Registration to a Couple of Reproductive Traits in Japanese Black Cows
}

\author{
Sudirman BACO, Hiroshi HARADA \\ and Riichi FUKUHARA
}

Faculty of Agriculture, Miyazaki University, Miyazaki-shi 889-21

(Received July 31, 1997)

\begin{abstract}
A study was made on the genetic relationships of body measurements at registration to a couple of reproductive traits in Japanese Black females. Genetic parameters were calculated using a REML procedure under multiple-trait animal model. The field records on six body measurements and three reproductive traits of 14,881 Japanese Black females were analyzed. Body measurements included withers height, chest girth, chest depth, rump length, thurl width and body weight, and reproductive traits included age at first calving, first calving interval and gestation length. Heritability estimates for body measurements were moderate $(0.33$ for chest girth, 0.35 for chest depth, 0.39 for rump length, 0.34 for thurl width and 0.39 for body weight) to high (0.45 for withers height), while those for reproductive traits were low $(0.04$ for age at first calving to 0.17 for gestation length). High and positive genetic correlation coefficients of 0.50 to 0.87 were obtained among body measurements. Most body measurements had negative genetic relationships with reproductive traits. Thurl width had a closest genetic correlation $(-0.38)$ with age at first calving, while rump length had a closest correlation $(-0.34)$ with calving interval. Withers height, which was thought to be an important indicator for growth performance and first insemination, had only low and negative genetic correlation with age at first calving $(-0.19)$, though it had a negative and closest correlation with gestation length $(-0.48)$. Body weight had no close genetic correlation with any reproductive traits $(-0.12$ to -0.16$)$. Concerning reproductive traits, it may be said that all of the body measurements at registration are not always good indicators for feasible reproductive performance, and that a more efficient method for body measurement should be developed in the near future in order to predict breeding values of reproductive traits such as age at first calving and calving interval, and longevity of replacement heifers and cows.
\end{abstract}

Anim. Sci. Technol. (Jpn.) 69 (1): 1-7, 1998

Key words : Genetic parameters, Body measurements, Reproductive traits, Japanese Black cows

The body measurements including withers height and body weight were proposed for the first time as indicators for ideal body-type of registered Japanese Black heifers and cows at 1933 in Tottori Prefecture ${ }^{2}$. At present time measurement of dimensions including withers height, chest girth, chest depth, hip length, thurl width and body weight of Japanese Black heifers are required just before judging for reg- istration. The actual figures for body measurements are scored for evaluation of the animals. Especially it was thought that in judging Japanese Black cattle, withers height is most important indicator for evaluating the growth performance of the animals ${ }^{17}$.

A number of research works have been carried on body measurements for improvement of Japanese Black cattle. Firstly 


\section{BACO, HARADA and FUKUHARA}

standard growth curves were determined using linear and non-linear model equations ${ }^{3,5}$. Secondly genetic parameters for body measurements were estimated by the least squares variance analysis method ${ }^{15)}$. Recently a great attention is paid to body measurements of the cows at registration as one of supplementary factors that assist to increase the accuracy of prediction of breeding values of cows for carcass traits ${ }^{10-12)}$. The prediction of breeding values for body measurements of the cows, the genetic trends of body measurements and the genetic relationships of body measurements to reproductive performance in breeding of Japanese Black cows are also considered ${ }^{14}$. However, the amount of informations from the records of body measurements in the improvement of Japanese Black cattle are not sufficient.

The present study was conducted to examine the relationships of body measurements at registration to a couple of reproductive traits in registered Japanese Black cows, and to evaluate body measurement as indicator for feasible reproductive performance in Japanese Black cows.

\section{Materials and Methods}

\section{Data}

Six body measurements and three reproductive traits of 14,881 Japanese Black females and their pedigree information were collected from Wagyu Registry Association and Miyazaki Livestock Improvement Association. The animals were born in 1989 and 1991, and were registered for the fundamental and reserved classes in 1991 and 1992. All the animals were measured six body measurements at registration between 14 to 29 months of age and they produced two progenies. The body measurements analyzed included withers height, chest girth, chest depth, rump length, thurl width and body weight, and the reproductive traits included age at first calving, calving interval and gestation length. Calving interval was defined as interval between first and second calvings. The gestation length was determined as average length of the first and second gestations. The records of the animals were eliminated by following three restrictions; (1) animals with no full set of records of body measurements and reproductive traits, (2) animals with abnormal values which were larger or smaller than mean $\pm 3 \mathrm{SD}$ (standard deviation) for body measurements and gestation length, (3) those animals which exceeded the average plus $3 \mathrm{SD}$ in age at first calving and calving interval, respectively.

\section{Analytical procedure}

A multiple-trait animal model was applied for the estimation of variance and covariance. The linear mixed model used was

$$
\mathbf{y}=\mathbf{X b}+\mathbf{Z u}+\mathbf{e}
$$

where, $\mathbf{y}$ is an observation vector on traits $; \mathbf{b}$ is unknown vectors of fixed effects; $\mathbf{u}$ is unknown vectors of total genetic merit effects (random effects) ; $\mathrm{e}$ is a random vector of residual effects; $\mathbf{X}$ and $\mathbf{Z}$ are incidence matrices relating $\mathbf{b}$ and $\mathbf{u}$ to $\mathbf{y}$, respectively. Animals and residual effects were treated as random with variances $\mathbf{G} \otimes \mathbf{A}$ and $\mathbf{E} \otimes \mathbf{I}$, respectively. $G$ and $\mathbf{E}$ denote covariance matrices among traits for animal and residual effects, respectively; A denotes additive genetic relationships among the animals ; $\otimes$ denotes Kronecker product ${ }^{7}$. Genetic $(50,041$ levels) and residual effects were also included as random effects in the model. The fixed effects considered for body measurements and reproductive traits are shown in Table 1 . Feeding region (eight levels) and season of judgment (four levels) were included as fixed effects, and age at measurement, judging score and ratio of body weight to withers height $(\mathrm{BW} / \mathrm{WH})$ were considered as linear and quadratic covariates while inbreeding coefficient only as linear covariate. Ratio (BW : body weight)/(WH : withers height) was included as covariate in the model for reproductive traits to adjust body condition of cows ${ }^{14}$. In order to calcu- 
Relationships of Body Measurements to Reproductive Traits

Table 1. Fixed effects and covariates considered in analysis of traits

\begin{tabular}{lccc}
\hline Effects & $\begin{array}{c}\text { Body } \\
\text { measurement }\end{array}$ & $\begin{array}{c}\text { Reproductive } \\
\text { trait }\end{array}$ & $\begin{array}{c}\text { Body measurement } \\
\text { with } \\
\text { reproductive trait }\end{array}$ \\
\hline $\begin{array}{l}\text { Fixed effect (number of levels) } \\
\text { Feeding region (8) }\end{array}$ & Yes & Yes & Yes \\
Season of measurement (4) & Yes & Yes & Yes \\
Covariate (L : linear, Q : quadratic) & Yes & Yes & Yes \\
Inbreeding coefficient (L) & Yes & Yes & Yes \\
Age at measurement (L \& Q) & & Yes & \\
Judging score (L \& Q) & & & \\
\hline
\end{tabular}

late the relationships of body measurements to reproductive traits, age at measurement and ratio $\mathrm{BW} / \mathrm{WH}$ were excluded from the model.

Variance and covariance components were estimated by the restricted maximum likelihood (REML) method with expectationmaximization (EM) algorithm using sparse matrix inversion ${ }^{8}$. Residual covariances were assumed not to exist. Genetic base year was set at 1975 for both body measurements and reproductive traits.

\section{Results and Discussion}

\section{Basic statistics}

Basic statistics of body measurements and reproductive traits are presented in Table 2. The mean age at measurement was 20.5 months old which was younger than that (23.4 months old) reported by Oyama et al. $(1996)^{14)}$ for Hiroshima herd and that (22.9 months old) by Mukai et al. $(1993)^{11)}$ for Kagoshima herd. The mean value of $126.6 \mathrm{~cm}$ for withers height agreed completely with the figure reported by Mukai et al. ${ }^{11)}$. The mean value for age at first calving of 24.4 months old is smaller than that for all cows (25.4 months old) which were raised in Miyazaki prefecture in 1996 (personal information). The mean value for calving interval was 13.1 months, which was similar to that reported by Moriya et $a l_{.}{ }^{9)}$ and Oyama et al..$^{14)}$. However, the value of calving interval was still longer by almost one month than recom- mended value of 12 months. The mean value of the first two gestation length was 288.8 days which was one day longer than that reported by Moriya et al..$^{9}$ for Japanese Black cows, and also 3.8 days longer than that reported by Kumazaki and Mori ${ }^{6}$.

\section{Withers height}

Before registration, nominated heifers are requested to measure withers height, chest girth, chest depth, rump length, thurl width and body weight. In general, the growth of an animal is evaluated to compare own withers height to the value of standard growth curve at the specific age. In the many farms of Japanese Black cattle reproduction, age at first insemination or first mating of heifer is judged by withers height. First insemination for a heifer is recommended when her withers height reaches 116 to $118 \mathrm{~cm}^{17)}$.

As shown in Table 3 , heritability estimates for withers height was 0.45 which was larger than those for other five measurements. The present results support the fact that withers height is a best indicator among the body measurements for growth in heifers. The heritability estimate of 0.45 agreed completely with the value reported by Mukai et al. ${ }^{11}$ ) though it was higher than the value of 0.18 reported by Ujiie et al. ${ }^{16}$.

A considerable high genetic relationships of withers height were found to other body measurements. The genetic correlation coeffi- 


\section{BACO, HARADA and FUKUHARA}

Table 2. Basic statistics of body measurements and reproductive traits

\begin{tabular}{lrrr}
\hline & & \multicolumn{2}{c}{ Range } \\
\cline { 4 - 5 } \multicolumn{1}{c}{ Traits } & Mean $\pm \mathrm{SD}$ & \multicolumn{1}{c}{ Min. } & \multicolumn{1}{c}{ Max. } \\
\hline Body measurements) & & & \\
$\quad$ Age at measurement (mo.) & $20.5 \pm 2.0$ & 14.0 & 29.0 \\
Withers height (cm) & $126.6 \pm 2.5$ & 118.0 & 134.2 \\
Chest girth (cm) & $185.7 \pm 6.9$ & 163.0 & 208.0 \\
Chest depth (cm) & $66.1 \pm 2.2$ & 59.0 & 73.0 \\
Rump length (cm) & $50.1 \pm 1.8$ & 44.0 & 56.0 \\
Thurl width (cm) & $45.8 \pm 1.9$ & 39.0 & 52.0 \\
Body weight (kg) & $463.2 \pm 39.7$ & 335.0 & 587.0 \\
\hline Reproductive traits') & & & \\
Age at first calving (mo.) & $24.4 \pm 2.8$ & 20.0 & 36.9 \\
Calving interval (mo.) & $13.1 \pm 2.5$ & 9.9 & 23.8 \\
Gestation length (days) & $288.8 \pm 3.8$ & 275 & 302 \\
\hline
\end{tabular}

1) $\mathrm{n}=14881$ females

Table 3. Heritability estimates, genetic and phenotypic correlations for body measurements

\begin{tabular}{lcccccc}
\hline \multicolumn{1}{c}{ Traits } & $\begin{array}{c}\text { Withers } \\
\text { height }\end{array}$ & $\begin{array}{c}\text { Chest } \\
\text { girth }\end{array}$ & $\begin{array}{c}\text { Chest } \\
\text { depth }\end{array}$ & $\begin{array}{c}\text { Rump } \\
\text { length }\end{array}$ & $\begin{array}{c}\text { Thurl } \\
\text { width }\end{array}$ & $\begin{array}{c}\text { Body } \\
\text { weight }\end{array}$ \\
\hline Withers height & $0.45 \pm 0.03$ & 0.59 & 0.68 & 0.63 & 0.51 & 0.63 \\
Chest girth & 0.40 & $0.33 \pm 0.04$ & 0.87 & 0.56 & 0.61 & 0.86 \\
Chest depth & 0.49 & 0.58 & $0.35 \pm 0.04$ & 0.65 & 0.61 & 0.81 \\
Rump length & 0.45 & 0.39 & 0.37 & $0.39 \pm 0.03$ & 0.50 & 0.67 \\
Thurl width & 0.41 & 0.39 & 0.43 & 0.50 & $0.34 \pm 0.04$ & 0.77 \\
Body weight & 0.57 & 0.72 & 0.59 & 0.50 & 0.55 & $0.39 \pm 0.03$ \\
\hline
\end{tabular}

Heritability with S.E. are diagonal. Genetic correlations are to the right of the diagonal and phenotypic correlations are to the left of the diagonal.

cients ranged from 0.51 for thurl width to 0.68 for chest girth. The results indicate that heifers with high withers height may be superior in whole body size to those with low withers height. Mukai et $a l^{(1)}$ also reported that withers height had a high genetic correlation with chest depth (0.61).

Heritability estimates for age at first calving, first calving interval and gestation length as shown in Table 4 , were $0.04,0.05$ and 0.17 , respectively. Although negative genetic correlation could be estimated between withers height and age at first calving, the estimated value was -0.19 (Table 4). The low correlation suggests that Japanese Black cattle pro- ducers do not always judge the age at first insemination of heifers by size of withers height as recommended way. There was no genetic correlation between withers height and calving interval $(-0.02)$. The reason may be explained by the description of Oyama et $a l^{14)}$ that calving interval is a very complicated characteristics, and is also influenced by many factors such as size of calf, conception rate, nutritional management or efforts to detect estrus by producers. Okano et al. ${ }^{13)}$ examined the influence of body size on the calf production through life in Japanese Black cows and reported that there was no significant difference in age at first mating and age at first 
Relationships of Body Measurements to Reproductive Traits

Table 4. Heritability estimates for reproductive traits, and genetic correlations among body measurements and reproductive traits

\begin{tabular}{lccccccc}
\hline \hline \multicolumn{1}{c}{ Traits } & $\begin{array}{c}\text { Heritability } \\
\text { estimates }\end{array}$ & $\begin{array}{c}\text { Withers } \\
\text { height }\end{array}$ & $\begin{array}{c}\text { Chest } \\
\text { girth }\end{array}$ & $\begin{array}{c}\text { Chest } \\
\text { depth }\end{array}$ & $\begin{array}{c}\text { Rump } \\
\text { length }\end{array}$ & $\begin{array}{c}\text { Thurl } \\
\text { width }\end{array}$ & $\begin{array}{c}\text { Body } \\
\text { weight }\end{array}$ \\
\hline Age at first calving & $0.04 \pm 0.06$ & -0.19 & -0.03 & 0.01 & 0.14 & -0.38 & -0.16 \\
Calving interval & $0.05 \pm 0.06$ & -0.02 & -0.30 & -0.20 & -0.34 & -0.23 & -0.12 \\
Gestation length & $0.17 \pm 0.05$ & -0.48 & -0.20 & -0.21 & -0.21 & -0.18 & -0.12 \\
\hline
\end{tabular}

calving between the cows with large body size and those with small ones. A considerably close and negative genetic correlation was found between withers height and gestation length $(-0.48)$. The fact suggests that heifers with large withers height tended to have a shorter gestation length which may be explained by the fact that almost 60 per cent of total variation for gestation length are occupied by genetic source such as breed, sex and genotype of calf and so on ${ }^{6)}$.

\section{Chest girth and chest depth}

It is well known that there is a close phenotypic correlation between chest girth and body weight ${ }^{4}$. On the other hand, chest depth is used as an indicator of body size. It is reported that postnatal growth of chest depth and body length was greater than that of withers height and that it was smaller than thurl width ${ }^{3)}$. Heritability estimates for chest girth and chest depth were 0.33 and 0.35 , respectively as shown in Table 3 , and these values were larger than those $(0.14$ and 0.19$)$ reported by Mukai et al. ${ }^{11)}$ and were smaller than those $(0.44$ and 0.42 ) reported by Oyama et al. ${ }^{14)}$. Chest girth had a high genetic correlation coefficient of 0.87 with chest depth and 0.86 with body weight, while chest depth had also a high genetic correlation coefficient of 0.81 with body weight. The results may prove again that there is close relation between chest girth and body weight. Chest girth and chest depth had also high genetic correlation coefficients with rump length and thurl width.

As shown in Table 4, chest girth and chest depth were found to have no genetic relationships to age at first calving $(-0.03$ and 0.01$)$.
On the relationships of chest girth and chest depth to age at first calving. Oyama et al. ${ }^{14)}$ reported that low and negative genetic correlation coefficients were obtained for chest girth $(-0.08)$ and chest depth $(-0.20)$ using a twotrait animal model with ratio of body weight/ withers height as covariate, while moderate to high and negative coefficients were obtained for chest girth $(-0.37)$ and chest depth $(-0.42)$ under similar the model but without ratio of body weight/withers height. As the ratio of body weight/withers height is known as an indicator of nutritional body condition in Japan, it is necessary to consider nutritional body condition of heifers in discussing relationships of body measurements to age at first calving. Moderate and negative genetic relationships of chest girth and chest depth to calving interval $(-0.30$ and -0.20$)$ were estimated. Considering the fact that calving interval had a close phenotypic relationship to nutritional body condition, it is interesting that chest girth had a higher genetic correlation with calving interval than body weight. It is implied that chest girth is a better indicator for reproductive performance than body weight. Moderate and negative genetic relationships of chest girth and chest depth to gestation length $(-0.20$ and -0.21$)$ were found but the relationships are not as close as those of withers height.

\section{Rump length and thurl width}

Rump length had a low genetic correlation with age at first calving (0.14) while it had moderate and negative genetic correlations with calving interval $(-0.34)$ and gestation length $(-0.21)$, respectively. It is noted that 


\section{BACO, HARADA and FUKUHARA}

rump length had a strongest correlation with calving interval among body measurements test. Thurl width had low to moderate and negative correlation with age at first calving $(-0.38)$, calving interval $(-0.23)$ and gestation length $(-0.18)$, respectively. Especially it had a closest relationship with age at first calving among the body measurements. Oyama et al. ${ }^{14)}$ reported that thurl width had a negative genetic correlation coefficients of -0.21 and -0.48 under the model with and without the ratio of body weight/withers height, respectively.

\section{Body weight}

Body weight had a negative genetic correlation with age at first calving, calving interval and gestation length though the coefficients were low and ranged from -0.12 to -0.16 .

Bourdon and Brink ${ }^{1)}$ concluded that the genetic correlation between growth traits and age at first calving in beef cattle were consistently negative, indicating a favorable relationship between breeding values for growth and early reproduction. The results in the present study agreed with the conclusion of Bourdon and Brink ${ }^{1)}$, and it might be concluded that thurl width, rump length and withers height are important indicators for predicting age at first calving, calving interval and gestation length, respectively. Concerning evaluation of the reproductive performance of heifers, more attention should be paid to thurl width, rump length and withers height in addition to body weight. When the prediction of breeding values for reproductive performance of heifers and cows is required by Japanese Black cattle producers, it is predicted that body measurements will be more important than in today.

The results obtained above also suggest that anatomical portion of body measurements should be re-examined to evaluate the potential reproductive performance and longevity of heifers and cows.

\section{Acknowledgment}

The authors are greatly indebted to Wagyu Cattle Registry Association and Miyazaki Livestock Improvement Association for their kindness of allowing us to analyze a large number of field records on body measurements, reproductive traits and pedigree information.

\section{References}

1) Bourdon RM, Brink JS. Genetic, environmental and phenotypic relationships among gestation length, birth weight, growth traits and age at first calving in beef cattle. J. Anim. Sci., 55 : 543-553. 1982.

2) Central Association of Livestock Registry. History of development of livestock registry project. 329-335. Kanda Press, Ltd., Tokyo, 1980.

3) Fukuhara R, Obata T, Kihara Y. Growth and growth patterns of Japanese cattle in pasture. 1. Estimation of the growth curves and determination of the size ranges of normal growth. Bull. Chugoku Agr. Exp. Sta., 20 : 1-50. 1973.

4) Kidwell JF. A study of the relation between body conformation and carcass quality in fat calves. J. Anim. Sci., $14:$ 233-242. 1955.

5) Kumazaki K, Tanaki H, Kihara Y. Studies on Wagyu growth. Bull. National Chugoku Agr. Exp. Sta., B 4 : 73-108.1955.

6) Kumazaki K, Mori J. Statistic and genetic studies on the gestation length of Japanese breed of cattle. Bull. Chugoku Agr. Exp. Sta., 4 : 67-74. 1959

7) Misztal I, Lawlor TJ, Short TH, VanRaden PM. Multiple-trait estimation of variance components of yield and type traits using an animal model. J. Dairy Sci., 75 : 544-551. 1992.

8) Misztal I, Perez-Enciso M. Sparse matrix inversion for restricted maximum likelihood estimation of variance components by expectation-maximization. J. Dairy Sci., 76 : 1479-1483 1993.

9) Moriya $K$, Fukuhara $R$, Oshikawa $Y$, Harada $Y$, Harada H. Analysis of field records on the reproductive traits of Japanese Black cows. Anim. Sci. Technol. (Jpn.), 62 : 357-361. 1991.

10) Mukai F, Okanishi $T$. Accuracy of predicted breeding values by animals models when main and secondary traits are recorded in different sex. Anim. Sci. Technol. (Jpn.), 63:488-494. 1992. 
Relationships of Body Measurements to Reproductive Traits

11) Mukai F, Okanishi T, Yoshimura T. Genetic relationships between body measurements of heifers and carcass traits of fattening cattle in Japanese Black. Anim. Sci. Technol. (Jpn.), 64 : 865-872. 1993.

12) Okanishi T, Mukai F, Yoshimura T. Accuracy of prediction breeding values for carcass traits under an animal model incorporating body measurements of cows. Anim. Sci. Technol. (Jpn.), 64 : 896-903. 1993.

13) Okano A, Izaike $Y$, Shimada $K$, Oishi $T$. Influence of body size on the calf production in Japanese Black cows. Bull. National Chugoku Agr. Exp. Sta., B 28 : 13-22.1985.

14) Oyama K, Mukai F, Yoshimura T. Genetic relationships among traits recorded at registry judgment, reproductive traits of breeding females and carcass traits of fattening animals in Japanese Black cattle. Anim. Sci. Technol. (Jpn.), 67 : 511-518. 1996.

15) Shioya $Y$, Obata $T$, Fukuhara $R$. Growth and growth patterns of Japanese cattle in pasture. 3. Relationships of body measurement to body weight in growth female. Bull. Chugoku Agr. Exp. Sta., B 21 : 1-24. 1975.

16) Ujiie S, Yamaki K, Yamagishi T, Mizuma Y. An application of sire evaluation via BLUP methods of body measurement for Japanese Black heifers. Jpn. J. Zootech. Sci., $60: 817-823$. 1989.

17) Wagyu Registry Association. Handbook of Wagyu Improvement. 150-151. Wagyu Registry Association. Kyoto. 1992.

\title{
黒毛和種雌牛の登録時体測定值と繁殖性の遺伝相関
}

\author{
Sudirman BACO ・ 原田 宏・福原利一 \\ 宮崎大学農学部, 宮崎市 889-21
}

\begin{abstract}
黒毛和種堆牛の種牛能力の㕕種価評価ならびに合理的な体測定に関する基礎的知見を得ることを目的 として, 平成 3,4 年度に宮崎県で登録検查を受计た 14,881 頭の黒毛和種雌牛の基本・本原登録時体測 定値己繁殖性の遭伝率と道伝相関を多形質 REML 法によって推定した，推定対象形質としては，体測 定值として体高, 胸囲, 胸深, 尻長, か九幅掞よび体重の 6 形質, 繁殖性として初産月齢, 初産と 2 産 の間の分婏間隔㧍よび初産と 2 産の平均妊娠期間の 3 形質とした。体測定の遗伝率は体高 0.45 , 胸囲 0.33 , 胸㳭 0.35 , 尻長 0.39 , 汃九幅 0.34 および体重 0.39 と中位の推定值が得られたが, 体高加最も高い 值を示した。 また，体高は他の体測定部位との間に 0.50 から 0.87 の高い正の遺伝相関を示した。これら の結果は，現行の黒毛和種崔牛の体型審查においては，体高が発育の指標として広く使われていること の妥当性を支持するものであること，牛体の発育に関しては，体高を測定することによって，他の部位 の測定を一部省略できる可能性のあることを示唆するすのであると思われた，繁殖形質の遭伝率は，初 期月齢 0.04 , 分婏間隔 0.05 および娃娠期間 0.17 之それぞれ低い值であった. 体測定值はこれらの繁殖形

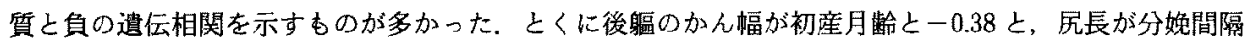
とー0.34 とそれぞれ最む密接な遭伝相関を示したことは，体高が妊娠期間と高い負の遺伝相関 $(-0.48)$ を示したこととともに注目された，以上の結果，黒毛和種雌牛の登録時に行われている体測定は，必ず しもそのすべてが当該雌牛の発育性や繁殖性などに関わる評価に適した指標とはいえず, 今後雌牛の初

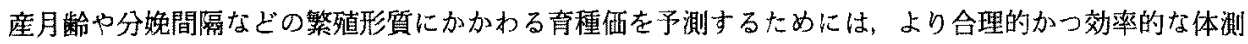
定法を発展させる必要があると思われた。
\end{abstract}

